Punch, S. (2001) 'Household Division of Labour: Generation, Gender, Age, Birth

Order and Sibling Composition’, Work, Employment \& Society, 15 (4):803-823.

\title{
Household Division of Labour: \\ Generation, gender, age, birth order and sibling composition
}

\author{
Samantha Punch \\ British Academy Postdoctoral Fellow \\ Department of Applied Social Science \\ University of Stirling \\ Stirling \\ FK9 4LA
}

Published in:

Work, Employment \& Society 


\section{Household Division of Labour:}

\section{Generation, gender, age, birth order and sibling composition}

For several decades there has been an on-going discussion over the ways in which household divisions of labour are organised and controlled, and the rights some household members have over others' labour. However, throughout the world, most studies of 'household' divisions of labour are actually reporting on the 'conjugal' distribution of labour, since they tend to discuss only adult participation in household work whilst ignoring children's contribution. The main focus of these studies has been on the unequal distribution of household labour and how women's greater contribution to domestic work relates to the inequality of women's position in society (Fenstermaker Berk 1980; Gerstel and Engel Gross 1987; Ironmonger 1989; Oakley 1974). Rarely do such accounts acknowledge that they are only discussing the spouses' division of labour whilst recognising that children also participate in household work (Hiller 1984; Van der Lippe 1994).

In the Majority World (the 'Developing World')', the debate has centred on gender relations and the economic significance of housework and reproductive, as opposed to productive, work (Bennholdt-Thomsen 1984; Harris 1981; Huang and Yeoh 1996; Pearson 1992; Stølen 1996; Wallerstein and Smith 1992). Some authors discuss the effects of modernisation and development on traditional gender roles by examining women’s increasing cash-earning opportunities (Jelin 1991; Masini and Stratigos 1991; Singerman and Hoodfar 1996). In the Minority World (the 'Developed World'), the recent focus has been on the continuing inequality of the domestic division of labour despite women's increased participation in paid employment (Baxter and 
Western 1998; Brines 1994; Gill 1993; Gregson and Lowe 1993; Layte 1993; Lennon 1994; Seymour 1992; Speakman and Marchington 1999; Warde and Hetherington 1993). Other studies in the Minority World claim that gender relations regarding household labour allocation are changing more significantly and that men are contributing a more equal share of the workload (Benjamin and Sullivan 1996; Coltrane 1989; Sullivan 2000). Whilst research concerning the sexual division of household labour is invaluable, particularly in highlighting gender inequality, by focusing only on the gendered allocation of adult household work, children and young people’s contributions are obscured.

This paper illustrates the importance of exploring intergenerational divisions of household labour as well as gender. However, it also argues that we should not stop at a gender and generational analysis of household labour allocation but that other intragenerational issues also need to be considered, such as age, birth order and sibling composition. In particular, the paper shows the importance of the sibling order which influences the ways in which household labour is organised, but is often neglected in sociological research. A consequence of not sufficiently recognising the generational distribution of household tasks has been to obscure the importance of birth order and sibling composition. Whilst a few studies of household divisions of labour have begun to consider generation and children's work contributions, there is a paucity of empirical data regarding intragenerational issues with the exception of gender. In particular, there is a lack of detailed analysis of the ways in which age, birth order and sibling composition impact upon household labour allocation. 
The paper begins by discussing the somewhat limited literature on children's participation in household work and then presents empirical evidence from rural households in Bolivia which shows that the division of household labour is worked out according to generation, gender, age, birth order and sibling composition. I argue that whilst adult household labour is highly determined by gender roles, children's labour often cuts across gender stereotypes and does not merely mirror the adult division of labour in rural households. The nature of generation-specific tasks are explored by presenting a detailed age-based division of labour in three different areas of unpaid household work: agriculture, animal-care and domestic work. The final part of the paper explores the ways in which birth order and sibling composition influence the distribution of children's household work. Whilst the paper is based on a case study of a rural community in a low-income country, it highlights important factors such as birth order and sibling composition which have frequently been overlooked or ignored in household divisions of labour in both the Majority and Minority World.

\section{Previous Research on Children's Participation in Household Work}

The literature on household divisions of labour in both the Majority and the Minority World focuses overwhelmingly on the gendered distribution of work whilst age and generational relations have been relatively neglected. Often when children are referred to in research on the sexual division of 'household' labour, they are briefly mentioned as a homogenous group of ‘children’ who help their parents (Geerken and Gove 1983; Gill 1993; Layte 1998; Wallerstein et al. 1982). Children’s unpaid household work is frequently underestimated or undervalued. Goddard and White noted that it is often disguised as 'training' or 'helping' (1982: 466). Such a view 
undermines the value and importance of children's work as having worth in its own right, in much the same way that previously women's work was trivialised as inferior to men's (Oakley 1974; Fenstermaker Berk 1980). Salazar (1988) and Reynolds (1991) have commented that many children's tasks are not recognised as work. This can also be compared to the invisibility and undervaluation of women's work (Schildkrout 1981: 93). Many children are far more than 'mere helpers', often assuming full responsibility for certain household tasks particularly in the Majority World where their contribution can be crucial.

Over the past three decades there have been a scattered number of studies throughout the world that discuss children's contribution to household work. From the late 1970s until the early 1990s, research on children's involvement in unpaid household labour was conducted by asking parents about their children's contribution (Blair 1992; Cogle and Tasker 1982; Gill 1998; Goodnow 1989; Peters and Haldeman 1987; Shamgar-Handelman 1986; Thrall 1978; White and Brinkerhoff 1981; White and Brinkerhoff 1987). Within the new sociology of childhood it is now considered one-sided only to ask adults to speak on behalf of their children (James and Prout 1990). In the new social studies of childhood, children are widely recognised as competent social actors who should be given the opportunity to express their own views about issues which concern them (Boyden et al. 1998: 170; Sinclair 1996: 87). As this article will show, children's perspectives can differ from those of adults (see also Butler and Williamson 1994) which is why it is important to ask household members about their own involvement in household work rather than rely on the reports of what others say they do. In particular, asking just one member about the rest of the household, can lead to underestimating the other person's contribution 
(Thrall 1978). Furthermore, this paper will illustrate the need to include observational methods in order to observe labour allocation in practice instead of only relying on what people say they do.

The extent and nature of children's unpaid household work varies in different societies throughout the world according to cultural norms (particularly gender ideologies), wealth of households, parents' employment status, household composition and whether it is a rural or urban location. Therefore, whilst it is difficult to generalise, there are some broad similarities and differences according to different world areas. Studies in both the Majority and Minority World indicate that the amount and type of children's participation in tasks accumulates as they get older (Cogle and Tasker 1982; Shamgar-Handelman and Belkin 1986; Thrall 1978; White and Brinkerhoff 1981). As well as acquiring a greater workload, the tasks they perform increase in complexity and responsibility (Gill 1998; Shamgar-Handelman and Belkin 1986).

In the Majority World, children begin to contribute to household tasks as soon as they are capable and from a very early age (Gill 1987; Shamgar-Handelman and Belkin 1986). Their level of responsibility for tasks tends to be earlier than that of children in the Minority World (Boyden et al. 1998: 34). It is widely acknowledged that children in the Majority World are expected to undertake unpaid household labour on a routine basis and contribute to the survival of the household (Guijt et al. 1994; Johnson et al. 1995; Reynolds 1991; Shamgar-Handelman and Belkin 1986). However, in the Minority World, children's contribution has been considered to be more symbolic: for socialisation purposes rather than because of economic need 
(Thrall 1978; White and Brinkerhoff 1987; Zelizer 1985) although some authors disagree (Gill 1998; Goodnow 1988; Morrow 1996).

The important point to bear in mind is that for a variety of reasons many children worldwide contribute to household labour and it is important to understand how their work is distributed. Some authors have found that children's participation in household labour increases according to the nature of parents' employment, such as in dual-earner households (Blair 1992; Thrall 1978), or single-headed households (Peters and Haldeman 1987; White and Brinkerhoff 1981). Unsurprisingly, most studies of children's household work have focused on gender as the main determinant of labour allocation (Burns and Homel 1989; Deere and León 1982; Johnson et al. 1995; McHale et al. 1990; Thrall 1978; White and Brinkerhoff 1981). It has been found that female children help their mothers in the domestic arena whilst male children help their fathers with household maintenance (McHale et al 1990) or with agricultural work (Garcia Ramon et al. 1993; Robson 1996; Stølen 1996). Many accounts show that girls have a greater burden of labour than boys, especially in the Majority World (Johnson et al. 1995; Niewenhuys 1994; Reynolds 1991; Robson 1996). In the Minority World, girls also participate more than boys in domestic work but not in household maintenance and repairs (Burns and Homel 1989; Cogle and Tasker 1982). An exception is White and Brinkerhoff's research in Nebraska which found that boys began working earlier than girls (1981) and they had slightly more chores until their teens (1987).

However, by concentrating on gender as the vital determinant of children's labour distribution in households, the effects of birth order and sibling composition have 
been overlooked. There is some evidence that the importance of birth order varies in different societies, particularly in relation to the eldest child being more privileged as the only legitimate heir (Boyden et al. 1998). Yet very few studies have explored the impact of birth order on children's allocation of household tasks. ShamgarHandelman and Belkin's work in Jerusalem found that firstborn children participate more and at an earlier age than their younger siblings (1986: 71). Brody and Steelman (1985) explored the impact of the gender distribution of sibling compositions, showing that children's work is less likely to be divided according to gender norms if only girls or only boys were present in households. The study presented here contributes to this scarce research by providing detailed evidence of the ways in which birth order and sibling composition can reverse traditional gender roles. It shows that in rural Bolivia both boys and girls engage in agricultural, animal-related and domestic work indicating that the household division of labour varies according to gender, generation, age, birth order and sibling composition. 


\section{The Study}

The paper draws on ethnographic research which I carried out in Churquiales, a rural community ${ }^{2}$ in Tarija, southern Bolivia (Punch 1998). During the fieldwork, I lived for two extended periods in Churquiales (consisting of regular short visits over two years and a six months intensive period of fieldwork when I lived with two households from the community ${ }^{3}$ ). There were a total of 58 households and I visited 18 of them regularly in order to conduct participant observation and interview all the household members including children, young people, parents and grandparents. The sample of households was chosen to include households of different sizes with varied compositions such as young and old households, and those with mixed and single-sex siblings.

Household visits lasted from half an hour to a whole day depending on the availability of household members. During these repeated visits I accompanied different family members, particularly the children, on their varied household chores and carried out in-depth semi-structured interviews with fifteen parents and eight grandparents in order to discuss the nature and distribution of household work. At the community school I employed a variety of qualitative techniques mainly with the oldest thirty-seven school children between 8-14 years, which included: photographs, drawings, diaries and worksheets (Punch 2001a). Two of the worksheets focused on children's work for their household, using the same questions that adults were asked during the semi-structured interviews. For approximately one month, twenty-two of the school children wrote a diary of their lives, providing information about a variety of routine daily activities which went beyond stereotypical notions that girls merely 
help their mothers while boys only help their fathers. Since children's views can be different from adults' perspectives (Butler and Williamson 1994), in this study I asked both parents and children about the household division of labour. Any discrepancies which arose in their accounts were explored further, in particular by the use of participant observation during household visits which enabled me to observe the ways in which tasks were distributed in practice rather than only relying on what household members reported.

Most of the families own two or three hectares of land, which they use mainly to cultivate potatoes, maize and a selection of fruit and vegetables. They also tend to own a small amount of pigs, goats and chickens, as well as a few cows. Most of their agricultural and livestock production is for family consumption, but any excesses are sold in local and regional markets. Consequently, as their household production is mainly traditional and subsistence-based, the labour requirements are high. In agriculture the land has to be prepared and the crops are sown, fertilised, cured of any disease and finally harvested. Animals have to be fed and cared for everyday, including taking them out to pasture and rounding them up in the evening.

As there is a lack of basic services (there is no electricity or telephones, and there is only a limited supply of drinking water), there are no modern labour-saving technologies to help with domestic work, such as liquidisers or washing machines. Limited economic resources mean that market goods or services cannot be bought to replace unpaid household production as in more affluent households of the Minority World (Bittman et al. 1999). Food preparation is time-consuming and clothes have to be washed by hand in the river. Firewood has to be collected regularly and water has 
to be carried from the river on a daily basis. Thus, the agricultural, animal and domestic work of Bolivian rural households requires high levels of labour participation from all household members. The rest of this paper explores how that household labour is distributed by first looking at gendered divisions of tasks, secondly at the intergenerational allocation of work and finally at the intragenerational factors of age, birth order and sibling composition.

\section{Gendered Divisions of Household Labour}

The adult division of household labour in rural Bolivia, like many areas of the Majority World, is very gender-specific. Men undertake most of the agricultural work whilst women carry out the majority of the domestic work (Punch 1998). However, with children, gender is only one of several important factors in determining the division of labour. In rural Bolivia, the adult division of labour based on gender is not merely mirrored in children's division of labour. This contrasts with the findings of studies in Africa, India and Nepal (Johnson et al. 1995; Niewenhuys 1994; Robson 1996; Reynolds 1991) where gender discrimination appears to be more marked than in Latin America. This study found that gender norms were not so rigid when applied to children in Churquiales.

My ethnographic research in Bolivia indicates that children's work can only be divided by gender if the household composition enables them to undertake traditional gender roles. For example, the following diary extracts ${ }^{4}$ indicate a typical weekend day for eleven year old Basilio and his thirteen year old sister Valentina. They describe their daily routine for Saturday 30 November 1996: 
I got up at 6.32 in the morning and I went to fetch water from the river and I went to get firewood from the paddock. I went to have my tea with bread and I went to hoe peanuts with my mum and my dad until 11.30 in the morning. We went to have a pasta soup with goat's meat for lunch and afterwards we went to finish hoeing the peanuts until 3.36 in the afternoon and I went home. I went to bring the goats down (from the hills) to enclose them and also I tied up the donkey. I went to have a rice soup for supper and I went to sleep at $8.30 .^{5}$ (Basilio, 11 years)

I got up at 6.30 in the morning and I went to milk the goats. I brushed my hair and I lit the fire. I peeled potatoes and cut up meat and put it in the saucepan. I put pasta in the pot, I washed the dishes and I took lunch to where my mum was and I served lunch. I came back to the house and put maize on to boil and I went to fetch water from the river. I played with my brothers and sisters and I put the pot on to cook. I cut up onions and threw them in the pot with potatoes and rice, and I made the supper. I washed the dishes and served supper. I went to sleep at 8.30 at night. ${ }^{6}$ (Valentina, 13 years)

In this household, the children's work is strongly gender divided because the household composition allows them to fulfil stereotypical gender norms. They are the oldest siblings present in the household (they have two older sisters working as domestic live-in maids in the town), and because of their accumulated experience, they are both very capable of taking on adult-type responsibility for tasks. Basilio does agricultural work with his parents, while Valentina takes over her mother's domestic role. This example shows how gender can be an important factor in the division of children's labour. However, the following section of this paper argues that generation and age are more central than gender to understanding children's work roles in households. 


\section{Generational Divisions of Household Labour}

In Bolivian rural households, some jobs, in particular fetching and carrying tasks such as daily water collection from the river, are generation-specific, but genderneutral tasks. Adults will rarely be seen looking after animals or collecting water if they have children. Even when children have to go to school, they must collect enough water before they leave (approximately 25 litres) to last until they return home, when they will collect more. Only if for some exceptional reason, that more water was used than normal and more was needed to make the lunch, would the mother of the household go to fetch water, rather than wait for her children to return from school. Similarly, other tasks such as fetching firewood or feeding animals are also left for when children return from school in the afternoon. Therefore, even on schooldays when children have less time to carry out work for the household, they should not be seen as merely assisting their parents (see also Johnson et al. 1995). Children often combine work and school, and compensate by doing more work before or after school, or at weekends or during holidays.

Even though some household tasks are foremost children's tasks (particularly the collection of water and firewood and animal care), adults did not always acknowledge children as being the ones mainly responsible for such chores. For example, when asked who in their household carried out most of the agricultural, animal-related and domestic work, parents and children in Churquiales described agricultural work as a predominantly male task, and domestic work as mainly female. Yet, they differed when considering animal care: children nearly always considered it a child task whereas most parents suggested it was mainly the mother's task. Such a contradiction 
could result from respondents exaggerating the importance of their own contribution. Children may overemphasise the extent of their participation in animal care because they forget that their mothers have to do it whilst they are at school. Or more likely, women may equate the fact that they make the decisions about animal care (what to feed them, where they should be taken to pasture) with doing the actual physical labour, which tends to be more frequently carried out by their children.

This tension can be compared with Deere and León's research (1982) on women's participation in agriculture in Cajamarca, Peru, where women were said to be responsible for herding activities and the care of small farm animals. Yet such a claim is later contradicted:

If a child is available, he or she is sent out with the sheep each day, but if not, it is the adult woman who, between her other chores, must take the animals out to graze (Deere and León 1982: 66).

Their research indicates that animal care is foremost a generation-specific task, and only if a child is not available does it become a gender-specific task for women. When parents in rural Bolivia gave their answers to the questions about who does most domestic, agricultural or animal-related labour, they tended only to include adult members of the household in their responses. Adults may well control that particular area of work and make decisions about how it should be done, when and by whom, but they may not actually be the ones to do the majority of the labour. This illustrates how children's work is often not counted as 'work' by adults. In contrast, when children gave their answers, they frequently included two members of the household for each job area (an adult and a child) which is more likely to be a reflection of the actual division of labour. The discrepancy of their responses confirms the importance 
of asking people about their own work contributions rather than relying on the reports of other household members.

\section{Intragenerational Distribution of Work: Age}

It is well known that in the Majority World many children start doing jobs for their household from a very early age (Boyden et al. 1998; Gill 1987), and their responsibility soon increases as they grow older. Yet the dynamics of the hierarchy of children's work according to age are not so well known. This section provides detailed empirical evidence to show the ways in which children's work roles accumulate complexity and responsibility over time. As children get older they are physically more capable, socially more responsible and have acquired competence through experience and practice to take on certain tasks autonomously (see Tables 1-3). I asked the children in this study to write three lists of all the jobs and activities they knew how to do in agriculture, with animals and in the domestic sphere. From this list I drew up three tables indicating the jobs that the children themselves had mentioned and including others that I had observed older children performing. I asked children to write down the age when they could do each particular task on their own, or when they would be able to do them. I added their answers together and worked out the average which is the age given on Tables 1-3.

Table 1 shows how children's responsibility with agricultural tasks increases as they get older. They begin by doing very light-weight, physically easy tasks. Gradually the level of physical difficulty and skill increases with their competence and age. Some jobs such as harvesting maize or retrieving stored maize from trees are not difficult, 
but need a certain physical height for the child to be able to perform them. Other tasks, such as harvesting potatoes, do not require much skill or a particular knowledge but they are physically demanding jobs which require the child to be older and have greater physical strength. Some jobs have to be carried out by older children because they require precision and skill. For example, pruning fruit trees or ploughing in a straight line are jobs which must be done correctly, otherwise the quality and quantity of the harvest will be reduced.

Table 2 indicates how children's work progresses when related to animal care. They learn the first jobs as young as three years old, such as scaring animals away from the house or from crops. This is usually done with squeals of delight and is like a game to small children. Older siblings and parents encourage and applaud their efforts and young children proudly enjoy the attention they receive. Soon they start accompanying their parents or elder siblings on other tasks, learning how jobs should be done. As soon as they are physically able, they can progress to more responsible jobs. Letting the animals out in the morning or rounding them up and bringing them into their enclosure at night are not very difficult jobs, but a certain physical strength is needed to open and close the paddock doors securely so that the animals cannot get out. Animal-related jobs for children over ten years tend to require a certain knowledge or skill, rather than just physical ability, such as knowing how to kill an animal correctly, or how to tie up oxen or load a donkey in the correct, most efficient manner. For example, one mother explained:

Everyone in the country learns how to skin a pig. From ten years upwards they begin to help and it depends on the strength they have as to whether they do it alone 
or not. My son knows how to do it and helps, but he doesn't do it alone. ${ }^{7}$ (Eudalia, parent)

She also commented how difficult it can be to kill an animal for the first time on one's own:

A chicken isn't difficult, what is difficult is to kill a goat. The first time I killed a goat I was scared, but I was alone and I had to do it. I was scared that it'd get away from me, but I knew how to cut it, it's just I didn't know how to do it by myself. I felt sorry for it too. But once it was dead, I was all right. ${ }^{8}$ (Eudalia, parent)

Children accumulate such knowledge through time, whilst participating in the task with others, observing and practising until they have sufficient experience and skill to carry it out competently and autonomously.

Table 3 shows how children's domestic duties increase as they grow older, depending on knowledge, physical capability and a sense of responsibility. For example, to look after younger siblings, parents must be able to trust that their children will attend them constantly, not letting them get into any danger. Such a job requires more responsibility than physical strength, although the older child must also be able to physically lift up the younger sibling. Again, competence is acquired through practising the task initially as a helper before being able to carry it out unaccompanied.

Most of these jobs may be carried out by children younger than the age groups suggested here. This tends to be the case when children are helping older siblings or parents to do a particular task. For example, many young children can be seen helping adults to wash clothes well before they are ten years old. Some may do so as young as five or six years old. One mother explained that her eight year old daughter: 'Knows how to wash but sometimes she doesn't get the stains out very well, and when it is adults' clothes, she can't wring the soap out, such as if it's a heavy pair of jeans. ${ }^{99}$ The ages given in the above tables indicate the ages that children can perform those jobs alone, without guidance or help from an adult or older sibling. 
It is commonly assumed that in the Majority World children as young as ten years old can do adult work (Reynolds 1991). The tables indicate that although children of ten years old can do many adult tasks independently, some require further physical ability and/or a certain knowledge or skill. In Churquiales, such competence is usually acquired with greater experience when the child is older, at about thirteen or fourteen years of age. Ten year olds may be able to do some, but not all adult work.

Therefore, generation-specific tasks not only include child-specific tasks but also more adult-specific tasks which children are least likely to perform. In Churquiales, when I asked children and their parents about which jobs children did not yet know how to do, both groups gave similar responses: ploughing with oxen, pruning of trees, curing plants with chemicals, giving an animal an injection, killing a large animal and making local speciality dishes such as spicy chicken or beef ${ }^{10}$. Such jobs either involve danger, require greater physical strength, or a particular knowledge and skill, which young people tend to learn in their late teens.

Consequently, a close examination of the hierarchy of children's work roles within households emphasises that children's work can be both similar to and different from that of adults. Some of the work which children do is exactly the same as adults' work, such as much food preparation and some planting and harvesting jobs. Such tasks depend on competence built up through practice rather than biological or physical requirements which vary with age. However, many children do not have the physical size, strength or height to do some adult tasks, such as ploughing or reaching maize stored in trees. Yet children do tend to have higher energy levels than adults, which makes them particularly suitable for running errands or running up hills to round up animals. They may be able to do such tasks more quickly than adults, or that may be a convenient excuse which adults use to avoid doing them. Similarly, the collection of water and firewood tends to be a child-specific task, but, is this because children can do it as it only requires limited strength, or because it is a tedious daily task and adults would prefer not to do? The unequal power relations in households mean that children can be delegated tasks which adults would rather avoid, as well as releasing adults so they can carry out tasks which children may be physically unable to fulfil. 


\section{Intragenerational Distribution of Work: Birth Order and Sibling Composition}

The discussion so far has shown that household division of labour is worked out according to gender, generation and age as well as household members' physical capabilities and competencies. However, these do not account for all the contingencies of household labour allocation and the dimension of siblingship needs also to be considered. For example, Hipólita is the second child of an all female sibling household. She is ten years old, and her diary describes how she fulfils a variety of 'male' and 'female' tasks for her household. The following extract shows what she did on Saturday 9 November 1996:

I got up at 6 in the morning. First I went to wash my face, and I went to serve myself some tea which I had with tortillas. Afterwards I went to wash the dishes and I went to harvest peas. Then I went to feed the dogs and then we went and had lunch. Afterwards I went to put soil on the potatoes, we had tea with tortillas and then I went to make a wall and to stop the irrigation water. I went to do my diary and then we went to sleep at 9 at night. ${ }^{11}$ (Hipólita, 10 years)

Hipólita switches easily between stereotypical 'male' and 'female' roles, as she engages in both agricultural and domestic work. She has no male sibling; she and her sisters share out all the necessary tasks regardless whether they are perceived as traditionally male or female duties. Her household is an exception in that there are seven female, and no male children. Yet many other households have sibling compositions where the older siblings are either male or female. In such situations, the tasks are divided according to age rather than gender, at least whilst the younger siblings are not physically capable of taking on older children's work. Similarly, when older siblings leave the household in search of migrant work, then the next sibling has to take over their role whether or not they are of the same gender. Thus, birth order and sibling availability can be more important than gender in the division of children's labour for the household. 
This paper has shown that as children acquire the competence, physical ability or the responsibility to do different jobs, their workload increases. However, as children get older and acquire 'older' jobs to do, they gradually abandon their 'younger' jobs, providing the sibling composition allows them to do so. For example, older children (about thirteen years and above) rarely go to fetch water or firewood if they have younger siblings. They may chop up a large piece of firewood with an axe, but they are unlikely to have fetched it themselves. This is because chopping up wood with an axe is a physically demanding and skilful job which is quite respectable for an older child to do. The job hierarchy according to age and ability not only indicates at what age certain jobs tend to be done, but it also reflects at what age certain jobs should not have to be done. As older siblings gain new responsibilities, they pass down their duties to younger siblings, in the same way that parents delegate jobs to their children. Nevertheless, just as adults without children, or with very young children (under fives), can be seen doing child-specific tasks, so older children have to do such jobs when younger siblings are too young or do not exist. Tasks can only be divided according to gender and generation if the household composition allows them to. 
The exact age at which children learn to do a particular task varies according to birth order and sibling composition. For example, Sebastián is nineteen years old and is the eldest male sibling in his household, so he was encouraged to learn jobs from quite an early age. His father taught him how to plough when he was ten years old, but his younger brother Alfredo is eleven years old and still does not know how to plough. Alfredo does not need to learn yet, because Sebastián still lives at home and does the ploughing. However, as their mother pointed out, Sebastián has been thinking of going to Argentina to work, so Alfredo will have to learn. When Sebastián leaves, Alfredo will be expected to take over all of his brother's obligations. In turn Alfredo will pass his duties to the next sibling, his sister Angélica.

There is more pressure on the oldest sibling to learn to do jobs earlier than on their younger siblings. Older siblings tend to shoulder more responsibility, because parents often find it easier to keep telling the older sibling to do a particular task rather than to teach a younger sibling, even if they could physically do it. As one mother says: 'She's the oldest so she knows how to do more things, so we send her to do more., ${ }^{12}$ This partly explains why older siblings may also migrate at an earlier age than their younger siblings, since they may feel the pressure of their responsibilities. One father explained that he migrated at fourteen years of age mainly because he was fed up with having to do everything at home. He felt that if he left, his younger siblings would finally be forced to contribute more to the household work.

Younger siblings may learn tasks later than their older siblings, but they experience extra pressure when they grow up to stay in the household and not migrate, as that will mean leaving the parents alone. Whereas their older sibling may have migrated at 
fourteen, the youngest may be pressurised by parents and older siblings to delay migration until he/she is at least seventeen or eighteen years of age. They may then have to carry out many of the household jobs alone, if all the older siblings have left. Therefore, it tends to be the middle siblings who receive less pressure in terms of whether to stay or leave the household, and in terms of the extent of their obligations. They always have either older or younger siblings to help them carry out household tasks, so rarely find themselves shouldering all the work alone.

\section{Conclusion}

In Bolivian rural households I have shown that children start by doing fetching and carrying errands for their households, and these are gender-neutral. The first jobs that children learn to do between the ages of 3-6 years are not gender-specific (see also Schildkrout 1981). The next age period of 7-9 years when children's responsibilities begin to increase is relatively gender-neutral (see also Bekombo 1981). Only if other siblings are available do jobs at this age become gender-specific, otherwise they are child-specific jobs regardless of gender. Once children are ten years and above their jobs become increasingly more gender divided. When I asked parents at what age they consider children's jobs to change according to gender, their responses varied between 10 and 14 years of age. This is usually because by this age there are likely to be other siblings available to work allowing jobs to be divided according to gender as well as age. This finding coincides with other research in the Majority World which has shown that gender roles are not static during childhood (Bekombo 1981: 120; Schildkrout 1981: 95). For example, Blanchet (1996) showed that girls and boys in Bangladesh take on increasingly gender-specific roles as they pass through childhood. 
Therefore, whilst gender is a vital component in determining the adult division of household labour, it is not the most important factor in children's work.

This paper has argued that household labour is distributed according both to gender and generation, and that the allocation of children's work within the household is determined also by age, birth order and sibling composition. Therefore, this article has provided evidence that it is not sufficient only to consider gender relations in households but generational relations should be examined. It has often been assumed that a gender analysis of the division of adult household labour is transferable to children, but such assumptions overlook the hierarchies within children's work according to competence, physical ability and age. This coincides with White and Brinkerhoff's findings in Nebraska as they found that the greater workload on rural farms results in a practical need to complete the tasks according to age and ability regardless of gender norms (1981: 177). In rural farming areas world-wide, the amount of household labour far outweighs that of urban areas since it includes agricultural and animal-related work as well as domestic labour. It is worth remembering that globally most children live in rural areas (Johnson et al. 1995) where subsistence and cash farming production is the main household livelihood, blurring distinctions between home and work. In such rural households the heavy workload of tasks have to be completed and this often overrides concerns for maintaining gender norms.

Other studies have also found that although gender-based divisions in children's household work exist they are more flexible than those of adults and are not rigidly maintained (Shamgar-Handelman and Belkin 1986). For example, when children's 
work is required as in dual-earner families then their participation can be more important than parents' views of appropriate sex-role tasks (McHale et al 1990). Similarly, Adagala found that on plantations in Kenya children's work would sometimes be divided more on the basis of age than gender (1991). Other factors such as age and availability of household members can therefore become more important than gender.

Hence, when looking at the nature of children's contribution to household labour, it is not adequate only to explore child-adult relations and differences between boys and girls. This paper on Bolivian rural households has highlighted the importance of birth order and sibling composition, and their potential significance now needs to be considered in other contexts as we cannot assume that they are not important factors in the household division of labour in urban areas or in other societies. Therefore, whilst this paper is based on a case study from the Majority World, it may have useful implications for studies of household labour in the Minority World. More quantitative research could also be useful in order to explore further the extent to which children's division of labour is dependent on the sex, age and composition of siblings in both rural and urban contexts. The findings of this paper have challenged traditional conceptions of work in households by showing that categories such as gender and generation should be used with caution. We need to rethink the notion of household labour and unpick broad concepts since they are not universally applicable. It is insufficient only to consider differences between males and females or between children and adults. By using comparative material we are reminded that gender and generational norms vary in different societies and are cross-cut by other factors such as birth order and sibling composition which are frequently ignored. 
It is also worth mentioning at this point that sibling composition and birth order have not only been overlooked in research on household divisions of labour but also in other sociological studies of family relationships. The majority of sibling research has been conducted in psychology (for example Lamb and Sutton-Smith 1982; Stocker et al. 1989; Buhrmester and Furman 1990) but sociological research on family dynamics tends to focus on the relationship between spouses or between parents and children. My Bolivian research has revealed the need to explore further the effects of birth order and sibling composition not only in relation to household divisions of labour in other contexts but also in relation to other aspects of social life such as children's informal networks and access to household resources. The sociological neglect of the sibling order has led to current research which is addressing these issues and exploring children's experiences of their sibling relationships and birth order in the $\mathrm{UK}^{13}$.

This paper has argued that relations between children and adults, and between children, regarding the household division of labour are interdependent. Even from an early age children carry out some tasks independently and they should not be seen purely as helpers but active contributors in their own right. Their unpaid work not only benefits the household, reinforcing interdependent household relations, but also increases their sense of autonomy, enabling them to gain skills and competencies useful for their individual independence. Yet, we have to bear in mind that the expectations of gender and generational roles are often flexible and negotiated in practice according to ever-changing circumstances (Finch and Mason 1993; Niewenhuys 1994: 74). Elsewhere I have discussed how children actively negotiate 
their work roles both with their parents and with their siblings (Punch 2001b). In addition, cultural norms have a vital impact on gender and generational divisions of household labour. For example, gender boundaries appear to be more rigid and less likely to be crossed in Asia or Africa compared with Latin America. Thus, households are flexible units which, whilst accommodating stereotypical gender and generational norms, frequently have to adapt to changes in the availability of all its members to work, which may be on a yearly, seasonal, weekly or even daily basis.

\section{Acknowledgements}

I am grateful to the School of Geography at the University of Leeds and the British Federation of Women Graduates for their financial support of this study. In addition, I would like to acknowledge the support of the British Academy through awarding me a Postdoctoral Fellowship which has provided me with time to revise this research for publication. I am also grateful to Ian McIntosh, Alan Prout, Fiona Chrystall and Janet Maybin for their comments on an earlier draft of this paper. 


\section{References}

Adagala, K. (1991) 'Households and Historical Change on Plantations in Kenya', in E. Masini and S. Stratigos (Eds) Women, Households and Change, Tokyo: United Nations University Press.

Baxter, J. (1992) 'Power Attitudes and Time: The Domestic Division of Labour', Journal of Comparative Family Studies, 23, 2, 165-82.

Baxter, J. and M. Western (1998) 'Satisfaction With Housework: Examining the Paradox’, Sociology, 32, 1, 101-20.

Bekombo, M. (1981) 'The Child in Africa: Socialisation, Education and Work', in G. Rodgers and G. Standing (Eds), Child Work, Poverty and Underdevelopment, Geneva: International Labour Organisation.

Benjamin, O. and O. Sullivan (1996) 'The Importance of Difference: Conceptualising Increased Flexibility in Gender Relations at Home', The Sociological Review, 44, 2, 225-51.

Bennholdt-Thomsen, V. (1984) 'Towards a Theory of the Sexual Division of Labor', in J. Smith, I. Wallerstein and H. Evers (Eds) Households and the World Economy, Beverly Hills: Sage.

Bittman, M., G. Matheson and G. Meagher (1999) 'The Changing Boundary Between Home and Market: Australian Trends in Outsourcing Domestic Labour', Work, Employment \& Society, 13, 2, 249-73.

Blair, S. (1992) 'Children's Participation in Household Labor: Child Socialization Versus the Need for Household Labor', Journal of Youth and Adolescence, 21, 2, 241-58.

Blanchet, T. (1996) Lost Innocence, Stolen Childhoods, Dhaka: The University Press Limited.

Deere, C. and M. León de Leal (1982) Women in Andean Agriculture, Geneva: International Labour Organisation.

Bonnery, N. and E. Reinach (1993) 'Housework Reconsidered: The Oakley Thesis Twenty Years Later’, Work, Employment \& Society 7, 4, 615-27.

Boyden, J., B. Ling and W. Myers (1998) What Works for Working Children, Stockholm: Rädda Barnen and UNICEF.

Brines, J. (1994) 'Economic Dependency, Gender, and the Division of Labor at Home', American Journal of Sociology, 100, 3, 652-88.

Brody, C. And Steelman, L.C. (1985) 'Sibling Structure and Parental Sex-typing of Children’s Household Tasks’, Journal of Marriage and the Family, 47, 265-273. 
Burns, A. and R. Homel (1989) 'Gender Division of Tasks by Parents and Their Children’, Psychology of Women Quarterly, 13, 113-25.

Cogle, F. and G. Tasker (1982) 'Children and Housework’, Family Relations, 31, 395-99.

Coltrane, S. (1989) 'Household Labor and the Routine Production of Gender', Social Problems, 36, 5, 473-90.

Doucet, A. (1995) 'Gender Equality and Gender Differences in Household Work and Parenting’, Women's Studies International Forum, 18, 3, 271-84.

Fenstermaker Berk, S. (ed.) (1980) Women and Household Labor, London: Sage.

Fenstermaker Berk, S and A. Shih (1980) 'Contributions to Household Labor: Comparing Wives' and Husbands' Reports', in S. Fenstermaker Berk (ed.) Women and Household Labor, London: Sage.

Finch, J. and Mason, J. (1993) Negotiating Family Responsibilities, London: Routledge.

Garcia-Ramon, M., M. Vilarino, M. Baylina and G. Canoves (1993) 'Farm Women, Gender Relations and Household Strategies on the Coast of Galicia', Geoforum, 24, 1, 5-17.

Geerken, M. and W. Gove (1983) At Home and At Work: The Family's Allocation of Labor, London: Sage.

Gerstel, N. and H. Engel Gross (Eds) (1987) Families and Work, Philadelphia: Temple University Press.

Gill, G. (1993) 'Gender Roles, Negotiations and Coping Strategies: A Qualitative Study of Two-Income Couples', International Journal of Sociology of the Family 23, 51-65.

Gill, G. (1998) 'The Strategic Involvement of Children in Housework: An Australian Case of Two-Income Families', International Journal of Comparative Sociology, 39, 3, 301-14.

Gill, L. (1987) Peasants, Entrepreneurs and Social Change: Frontier Development in Lowland Bolivia, Boulder: Westview Press.

Goddard, V. and B. White (1982) 'Child Workers and Capitalist Development', Development and Change, 13, 4, 465-477.

Goodnow, J. (1988) 'Children's Household Work: Its Nature and Functions', Psychological Bulletin, 103, 1, 5-26. 
Goodnow, J. (1989) 'Work in Households: An Overview and Three Studies', in D. Ironmonger (ed.) Households Work: Productive Activities, Women and Income in the Household Economy, London: Allen \& Unwin.

Gregson, N. and M. Lowe (1993) 'Renegotiating the Domestic Division of Labour? A Study of Dual Career Households in North East and South East England', The Sociological Review 41, 3, 475-505.

Guijt, I., A. Fuglesand and Y. Kisadha (Eds) (1994) It is the Young Trees that Make a Forest Thick, A report on Redd Barna learning experience with Participatory Rural Appraisal, Kampala, Norway, London and Redd Barna: IIED.

Hiller, D. (1984) 'Power Dependence and Division of Family Work, Sex Roles, 10, 11/12, 1003-19.

Huang, S. and B. Yeoh. (1996) 'Ties That Bind: State Policy and Migrant Female Domestic Helpers in Singapore’, Geoforum, 27, 4, 479-93.

Ironmonger, D. (ed.) (1989) Households Work: Productive Activities, Women and Income in the Household Economy, London: Allen \& Unwin.

Jelin, E. (ed.) (1991) Family, Household and Gender Relations in Latin America, London: Kegan Paul International UNESCO.

Johnson, V., J. Hill and E. Ivan-Smith (1995) Listening to Smaller Voices: Children in an Environment of Change, Somerset: ACTIONAID.

Layte, R. (1998) 'Gendered Equity? Comparing Explanations of Women's Satisfaction With the Domestic Division of Labour', Work, Employment \& Society, 12, 3, 511-32.

Lennon, M. (1994) 'Relative Fairness and the Division of Housework: The Importance of Options’, American Journal of Sociology, 100, 2, 506-31.

Marsh, C. and S. Arber (Eds) (1992) Families and Households: Divisions and Change, London: MacMillan Press.

Masini, E. and S. Stratigos (Eds) (1991) Women, Households and Change, Tokyo: United Nations University Press.

McHale, S., W.T. Bartko, A.C. Crouter and M. Perry-Jenkins (1990) 'Children's Housework and Psychosocial Functioning: The Mediating Effects of Parents' SexRole Behaviors and Attitudes', Child Development, 61, 1413-26.

Oakley, A.(1974) The Sociology of Housework, Bath: The Pitman Press.

Peters, J. and V. Haldeman (1987) 'Time Used for Household Work', Journal of Family Issues, 8, 2, 212-25. 
Punch, S. (1998) Negotiating Independence: Children and Young People Growing Up in Rural Bolivia, Ph.D Thesis, University of Leeds.

Punch, S. (2000) 'Children's Strategies for Creating Playspaces: Negotiating Independence in Rural Bolivia', in S. Holloway and G. Valentine (Eds), Children's Geographies: Living, Playing, Learning and Transforming Everyday Worlds, London: Routledge.

Punch, S. (In Press) 'Negotiating Autonomy: Children's Use of Time and Space in Rural Bolivia', in B. Mayall and L. Alanen (Eds) Conceptualising Child-Adult Relationships, London: Falmer Press.

Punch, S. (Forthcoming 2001) 'Multiple Methods and Research Relations with Children in Rural Bolivia', in M. Limb and C. Dwyer (Eds), Qualitative Methodologies for Geographers, London: Arnold.

Reynolds, P. (1991) Dance Civet Cat: Child Labour in the Zambezi Valley, Athens, Ohio: Ohio University Press.

Robson, E. (1996) 'Working Girls and Boys: Children's Contribution to Household Survival in West Africa', Geography, 403-407.

Salazar, M. C. (1988) 'Child Labour Policies and Programmes in Colombia', in A. Bequele, and J. Boyden (Eds), Combating Child Labour, Geneva: International Labour Organisation.

Schildkrout, E. (1981) 'The Employment of Children in Kano (Nigeria)', in G. Rodgers and G. Standing (Eds), Child Work, Poverty and Underdevelopment, Geneva: International Labour Organisation.

Seymour, J. (1992) ''No Time to Call My Own': Women's Time As a Household Resource', Women's Studies International Forum, 15, 2, 187-92.

Shamgar-Handelman, L. (1986) 'The Place of Children in the Household', Israel Social Science Research, 4, 1, 65-83.

Singerman, D. and H. Hoodfar (Eds) (1996) Development, Change, and Gender in Cairo: A View From the Household, Blooington and Indianapolis: Indiana University Press.

Speakman, S. and M. Marchington (1999) 'Ambivalent Patriarchs: Shiftworkers, 'Breadwinners' and Housework', Work, Employment \& Society, 13, 1, 83-105.

Stolen, K. (1996) 'The Gentle Exercise of Male Power in Rural Argentina', Identities, 2, 4, 385-406.

Thrall, C. (1978) 'Who Does What: Role Sterotypy, Children's Work, and Continuity Between Generations in the Household Division of Labor', Human Relations, 31, 3, 249-65. 
Van der Lippe, T. (1994) 'Spouses and Their Division of Labour', The Netherlands' Journal of Social Sciences, 30, 1, 43-62.

Wallerstein, I., W. Martin and T. Dickinson (1982) "Household Structures and Production Processes: Preliminary Theses and Findings", Review, 3, 437-458.

Warde, A. and K. Hetherington (1993) 'A Changing Domestic Division of Labour? Issues of Measurement and Interpretation’, Work, Employment \& Society, 7, 1, 23-45.

Weisner, T. and R. Gallimore (1977) 'My Brother's Keeper: Child and Sibling Caretaking’, Current Anthropology, 18, 2, 169-90.

White, L. and D. Brinkerhoff (1987) 'Children's Work in the Family: Its Significance and

Meaning', in N. Gerstel and H. Engel Gross (Eds), Families and Work, Philadelphia: Temple University Press.

White, L. and D. Brinkerhoff (1981) 'The Sexual Division of Labor: Evidence From Childhood', Social Forces, 60, 1, 170-181.

${ }^{1}$ Since most of the world's population live in the economically poorer countries of the 'developing world', namely Africa, Asia and Latin America, I refer to this world area as the Majority World. In contrast, the term 'Minority World' is used to describe the economically more privileged countries of the 'developed world': Europe, The United States, Australia and New Zealand. Whilst the use of these relatively new terms can be confusing, it enables the reader to reflect on the unequal relations between these two world areas previously referred to with negative connotations (Third/First World) or with geographical inaccuracy (North/South, or East/West).

2 The name of the community has been changed to Churquiales in order to maintain anonymity and confidentiality. The community has a population of 351 and it is $55 \mathrm{~km}$ from the regional capital.

3 This doctoral research developed as a result of initially working for two years in the same region of southern Bolivia on an European Union funded project (managed by Dr David Preston) titled: Farmer Strategies and Production Systems in Fragile Environments in Mountainous Areas of Latin America.

4 The only editing these diaries have received is in terms of punctuation: full stops and commas, and the omission of a few 'and's.

${ }^{5}$ Me levante a las 6.32 de la mañana y me he ido a traer agua del rio y me he ido traer leña del potrero y me he ido a tomar mi te con pan y me he ido a carpiar mani con mi mamá y tanvien mi papa asta las 11.30 de la mañana y se amos ido a almorzar una sopa de fideo con carne de cabra y despues se amos ido a acavar de carpiar el mani asta las 3.36 de las tarde y me he ido a la casa y me he ido a vajar las cabras para cerrarle y tanvien amarre el burro y me he ido a cenar una sopa de arros y me he ido a dormir a las 8.30 de la noche. (30 November 1996)

${ }^{6}$ Me levante a las 6.30 de la mañana y he ido a sacar leche y me he peinado y puesto la olla el fuego y pelado papas y cortado carne y echado a la olla y echado fideo a la olla y lavado los platos $y$ llevado el almuerzo andi mi mamá y le he dado a almorzar y me he venido y puesto mote y me he ido a traer agua del rio y jugado con mi ermanos y puesto la olla y he cortado cebolla y echado y papaz y hechado arros y echo la cena y labado los platos y dado a cenar y me he ido a dormir a las 8.30 de la noche. (30 November 1996)

${ }^{7}$ Todos en el campo aprenden a pelar cuchis. A partir de los 10 años por arriba empiezan a ayudar y depende de la fuerza que uno tiene para si hacen sólo o no. Mi hijo ya sabe y ayuda, pero no sólo. (9 August 1996)

${ }^{8}$ Una gallina no es difícil, lo que es difícil es mater un chivo. La primera vez que maté un chivo tuve miedo, pero estaba sola y tuve que hacerlo. Tenía miedo de que me escape. Pero yo sabía como 
cortar, si no que no sabía hacer solita. Me daba pena también. Pero cuando ya estaba muerto estaba bien. (9 August 1996)

${ }^{9}$ Sabe lavar también pero a veces no saca bien las manchas, y cuando es ropa de adulto, ella no puede sacar el jabón, tampoco si es un vaquero muy pesado por ejemplo. (Dolores, parent, 16 August 1996)

10 'Picante' (spicy chicken) and 'saice' (spicy beef) are typical Tarijan dishes. Most school children cooked soups, and simpler dishes such as stews.

${ }^{11}$ Me levante alas 6 de la mañana primero me fui a lavarme la cara y me fui a server el te y tome te con tortillas despues y me fui a lavar los servicios y me fui a pallar arvejas y despues me fui a dar de comer a los perros y despues emos ido a almorsar y despues me fui a echar tierra a las papas y emos tomado te con tortillas y despues me fui a pircar y vine a trancar a agua y vine a aser el diario y se despues semos ido a dormir alas 9 de la noche. (9 November 1996)

${ }^{12}$ Es la mayor entonces sabe hacer más cosas entonces le mandamos más. (Nélida, parent, 17 October 1996)

${ }^{13}$ I have been funded by the British Academy for a three year research project on sibling relationships based at the Department of Applied Social Science, Stirling University. 